\title{
MICROBIAL METABOLIC ACTIVITY ON A DRIP IRRIGATED COTTON FIELD AFTER TEN YEARS OF SALINE WATER IRRIGATION AND NITROGEN FERTILIZER APPLICATION ON ARID SOIL
}

\author{
GUO, H.N. - MA, L. J. - LI, M. Q. - HuANG, Z. J. - Min, W. \\ Department of Resources and Environmental Science, Shihezi University, Shihezi, Xinjiang \\ 832003, People's Republic of China \\ ${ }^{*}$ Corresponding author \\ e-mail: minwei555@126.com; phone: +86-1399-9536-214
}

(Received 30 $0^{\text {th }}$ May 2020; accepted $6^{\text {th }}$ Oct 2020)

\begin{abstract}
Irrigation with saline water can impact metabolic activity of soil microbial by altering the soil environment. The aim of this study was to reveal the influence of saline water irrigation on soil physicochemical properties and microbial metabolic activities. For this, a ten years saline water irrigation experiment was conducted in Shihezi, Xinjiang Province, China. Results indicated that saline water irrigation reduced soil $\mathrm{pH}$, total $\mathrm{N}(\mathrm{TN})$, organic matter $(\mathrm{SOM})$, and basal respiration (SBR), however, soil salinity increased significantly. Nitrogen application increased soil salinity, SOM, TN, and SBR, but reduced soil $\mathrm{pH}$. Saline water irrigation had significant negative effect on soil microbial metabolic activities. Nitrogen application significantly reduced soil microbial metabolic activities in the fresh water irrigation but had no significant effect under saline water irrigation treatment. Water salinity and $\mathrm{N}$ amount remarkably affected carbon (C) utilization patterns of the microbial communities, especially the utilization of amino acids, amines, and phenols. The D-Cellobiose, D-Xylose, D-Mannitol, $\beta$-MethylDGlucoside, i-Erythritol, $\alpha$-D-Lactose, L-Serine, L-Asparagine, LPhenylalanine, $\gamma$-Hydroxybutyric acid, Putrescine and 4-Hydroxy Benzoic Acid were the sole carbon sources. The results of this study increase our understanding of soil biological processes under saline conditions in arid regions.
\end{abstract}

Keywords: irrigation water salinity, nitrogen amount, basal respiration, microbial activity, biolog EcoPlate

\section{Introduction}

Salt-affected soils are common in arid areas. In these areas, there is not enough rainfall to leach salts from the root zone. Salt accumulation affects many soil properties. The Xinjiang province in northwest China has an arid continental climate, with low precipitation and high evaporation rates. Most shallow groundwater sources in this region have relatively high salinity, with an electrical conductivity of $>2 \mathrm{dS} \mathrm{m}^{-1}$ (Chen et al., 2010). Therefore, it is important to identify appropriate irrigation practices to avoid salt accumulation under saline water irrigation (Pereira et al., 2002). Drip irrigation is widely considered as the best method for saline water irrigation (Karlberg et al., 2007). Drip irrigation consists of frequent applications of small amounts of water over extended periods of time. However, even with careful management, irrigation with saline water may cause salt accumulation in soil. Increasing in soil salinity can affect soil water content, pH, SOM, and other soil physicochemical properties (Wong et al., 2010; Mavi et al., 2012), and may affect soil microbial communities. However, understanding about the effect of irrigation with saline water on the function of soil microbial metabolic activities is still incomplete and fragmented.

In the soil ecosystem, soil microbial are indispensable agents, responsible for decomposing organic matter, forming soil aggregates, and driving nutrient cycling 
(Critter et al., 2004; Kaye et al., 2005; Amini et al., 2016). Soil microbial is also sensitive indicators of environmental change. Soil microbial activity has direct impact on the soil ecosystems stability and function (Manzoni et al., 2012). Salt as a major stress effect to soil microbial has been received increasing attention. Previous studies have been done about the influences of salt on soil microbial physiology (Kakumanu and Williams, 2014), respiration (Chowdhury et al., 2011a), biomass (Yan and Marschner, 2012), community structure (Campbell and Kirchman, 2013), and C use efficiencies (Malik and Gleixner, 2013). For example, soil respiration from natural salt gradients is in most cases significantly negatively correlated with salt (Muhammad et al., 2008; Chowdhury et al., 2011b,c; Setia et al., 2011). Soil salinity may change soil microbial community composition (Gros et al., 2003; Gennari et al., 2007) because microbial species differ in their salt tolerance (Mandeel, 2006; Llamas et al., 2008). Sardinha et al. (2003) and Oren (2008) reported that soil salinity negatively affects microbiological processes either by reducing water availability to microorganisms or by influencing their cellular physiology and metabolic processes. However, less work has been done about the effect of water salinity on the soil microbial metabolic activity.

Soil microbial metabolic activity is widely used to evaluate soil processes and soil ecological functions. Increasing attention is being given to the effects of salinity on soil microbial metabolic activity. Studies have found that average well color development (AWCD) values decreased markedly with water salinity increased (Jin et al., 2014), indicating that water salinity may change the $\mathrm{C}$ utilization patterns of the soil microbial. Shen et al. (2008) also found that soil salt markedly decreased soil microbial community functional diversity. In addition, fertilization is another important agricultural management measure. Many studies found that fertilization can increase (Conde et al., 2005), reduce (Craine et al., 2007; Ramirez et al., 2010), or have no effect on soil microbial activity (Hobbie and Vitousek, 2000; Pangle and Seiler, 2002). However, little research has been done about the combined effects of irrigation with saline water and nitrogen $(\mathrm{N})$ fertilization on soil microbial metabolic activities under field conditions.

Therefore, it is important to understand the response of soil microbial metabolic activities to the changes in soil salinity that are induced by irrigation with saline water. We hypothesized that ten years saline water irrigation decreases soil nutrients and microbial metabolic activities in an arid area soil in China. The aim of our field located experiment was to use the Biolog EcoPlate method to reveal the effects of different irrigation water salinity and $\mathrm{N}$ fertilizer amount on soil microbial metabolic activity. We also compared $\mathrm{C}$ utilization patterns by the soil microbial communities in the different treatments. Our study can increase understanding about how water salinity and $\mathrm{N}$ amount influence soil microbial process. These results are useful for managing agricultural fields with saline water irrigation.

\section{Materials and methods}

\section{Field site and experimental design}

The long-term field located experiment that began in 2009 at the Shihezi University Agricultural Experiment Station, Shihezi City, Xinjiang Province, China $\left(44^{\circ} 18^{\prime} \mathrm{N}\right.$, $\left.86^{\circ} 02^{\prime} \mathrm{E}\right)$. The area has a continental climate. Annual precipitation and evaporation at the experiment station were $210 \mathrm{~mm}$ and $1660 \mathrm{~mm}$, respectively. The soil at the site is an alluvial, gray desert soil. Some of the soil physicochemical properties $(0-20 \mathrm{~cm}$ 
depth) at the start of the field located experiment in 2009 were as follows: bulk density, $1.33 \mathrm{~g} / \mathrm{cm}^{3}$; electrical conductivity $\left(\mathrm{EC}_{1: 5}\right), 0.13 \mathrm{dS} \mathrm{m}{ }^{-1} ; \mathrm{pH}, 7.48$; SOM, $16.8 \mathrm{~g} \mathrm{~kg}^{-1}$; $\mathrm{TN}, 1.08 \mathrm{~g} \mathrm{~kg}^{-1}$; available phosphorus $(\mathrm{P}), 25.9 \mathrm{mg} \mathrm{kg}^{-1}$; and available potassium $(\mathrm{K})$, $253 \mathrm{mg} \mathrm{kg}^{-1}$.

The experimental design was a $2 \times 2$ factorial with two irrigation water salinity levels [ECW of 0.35 and $8.04 \mathrm{dS} \mathrm{m}^{-1}$, representing as fresh water (FW) and saline water (SW), respectively] and two $\mathrm{N}$ application rates $\left(0\right.$ and $360 \mathrm{~kg} \mathrm{~N} \mathrm{ha}^{-1}$, representing as N0 and N360, respectively). These treatments were arranged in a randomized block design with 3 replications. The cropping system was continuous cotton (Gossypium hirsutum Xinluzao 52).

Figure 1 shows a diagram of the plot layout. Each plot $(16 \mathrm{~m}$ long $\times 1.2 \mathrm{~m}$ wide $)$ had four rows of cotton. The plots were mulched with one sheet of plastic film. Two drip irrigation lines were installed under the plastic film. The emitters were $0.4 \mathrm{~m}$ apart. Water was applied by drip irrigation at a rate of $2.7 \mathrm{~L} \mathrm{~h}^{-1}$. The same amount $(450 \mathrm{~mm})$ of water was applied to each plot annually, the irrigation water amount was controlled by a water meter. The timing of the irrigation events (irrigation intervals of 7 to $10 \mathrm{~d}$ ) was based on cotton growth requirements and soil moisture condition.

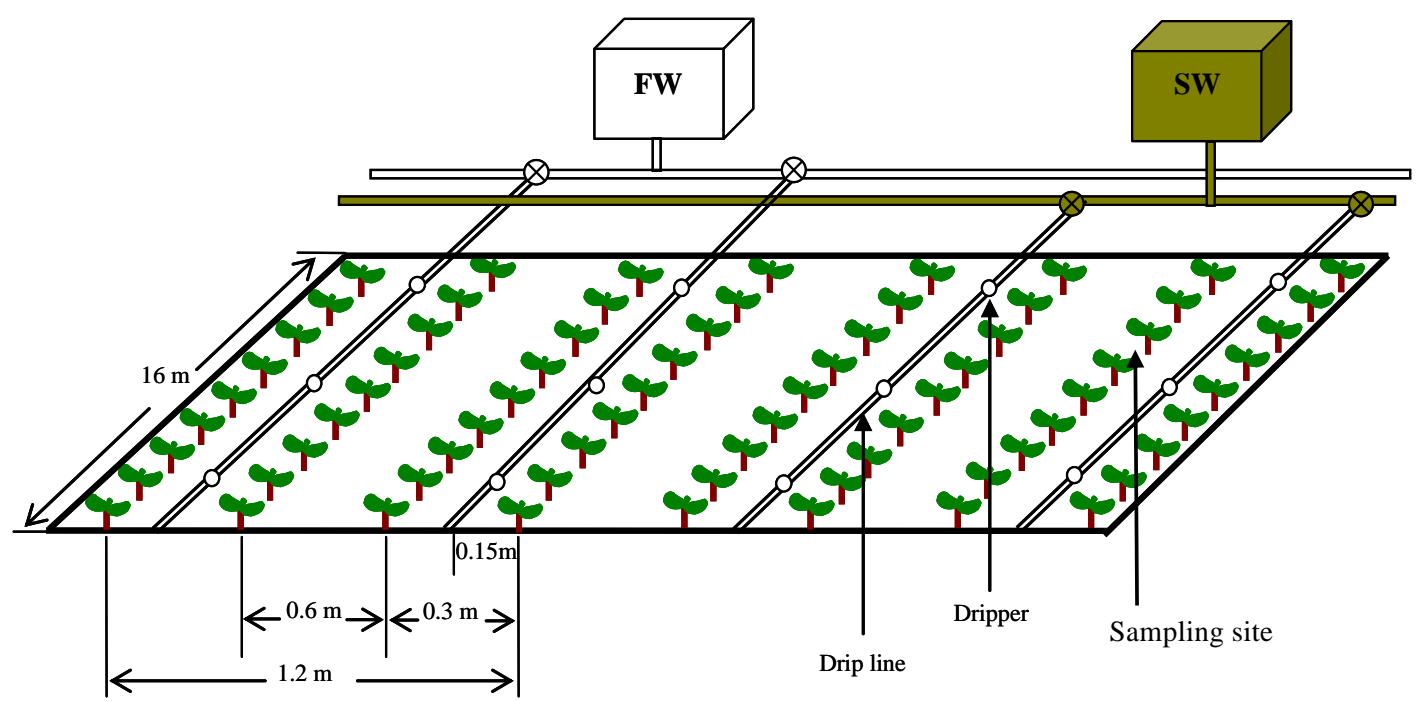

Figure 1. Layout of an experimental plot

The fresh irrigation water was obtained from a local well. The saline irrigation water was provided by adding $\mathrm{NaCl}$ and $\mathrm{CaCl}_{2}$ (a weight ratio of $1: 1$ ) to the well water. The ion concentrations of the irrigation fresh and saline water are presented in Table 1.

Table 1. Selected chemical characteristics of the irrigation water. EC, electrical conductivity; SAR, sodium adsorption ratio. The symbols $F W$ and $S W$ represent irrigation water salinities (EC) of 0.35 and $8.04 \mathrm{dS} / \mathrm{m}$, respectively. SAR, sodium adsorption ratio

\begin{tabular}{c|c|c|c|c|c|c|c|c|c|c}
\hline Water & $\begin{array}{c}\mathbf{E C} \\
\left(\mathbf{d S ~ m}^{-1}\right)\end{array}$ & $\mathbf{p H}$ & $\mathbf{S A R}$ & $\begin{array}{c}\mathbf{H C O}_{3}^{-} \\
\left(\mathbf{m e q ~ L}^{-1}\right)\end{array}$ & $\begin{array}{c}\mathbf{C l}^{-} \\
\left(\mathbf{m e q ~ L}^{-1}\right)\end{array}$ & $\begin{array}{c}\mathbf{S O}_{4^{2-}} \\
\left(\mathbf{m e q ~ L}^{-1}\right)\end{array}$ & $\begin{array}{c}\mathbf{C a}^{2+} \\
\left(\mathbf{m e q ~ L}^{-1}\right)\end{array}$ & $\begin{array}{c}\mathbf{M g}^{2+} \\
\left(\mathbf{m e q ~ L}^{-1}\right)\end{array}$ & $\begin{array}{c}\mathbf{K}^{+} \\
\left(\mathbf{m e q}^{-1}\right)\end{array}$ & $\begin{array}{c}\mathbf{N a}^{+} \\
\left(\mathbf{m e q ~ L}^{-1}\right)\end{array}$ \\
\hline FW & 0.35 & 7.52 & 0.16 & 0.98 & 2.46 & 0.73 & 2.44 & 1.18 & 0.33 & 0.22 \\
SW & 8.04 & 7.09 & 8.91 & 1.15 & 88 & 0.83 & 45.5 & 1.18 & 0.33 & 43.04 \\
\hline
\end{tabular}


Phosphorous and potassium fertilizers $\left(105 \mathrm{~kg} \mathrm{ha}^{-1} \mathrm{P}_{2} \mathrm{O}_{5}\right.$ and $\left.60 \mathrm{~kg} \mathrm{ha}^{-1} \mathrm{~K}_{2} \mathrm{O}\right)$ were applied at planting. The $\mathrm{N}$ fertilizer (urea) was applied in six equal amounts on June 20, June 27 , July 4, July 12, July 19, and July 26 through the drip irrigation system. The urea solution was stored in a plastic $15 \mathrm{~L}$ container and pumped into the irrigation system. The agronomic operations were the same in all of the plots. The $360 \mathrm{~kg} \mathrm{~N} \mathrm{ha}^{-1}$ amount is commonly used by local farmers.

\section{Soil sampling}

The soil samples in this study were collected on July 28, 2018. The cotton was at the boll opening stages. Three soil samples $(0-20 \mathrm{~cm})$ were collected from each plot. The soil samples were then mixed to form one composite sample per experimental plot. After sieving to remove stones, plant roots, then, the samples were put into sterile plastic bags and transported to the laboratory in a cooler and were refrigerated at $4{ }^{\circ} \mathrm{C}$ for microbial analysis.

\section{Soil chemical and microbial analysis}

$\mathrm{TN}$ and SOM were measured using the semimicro-Kjeldahl and the $\mathrm{K}_{2} \mathrm{Cr}_{2} \mathrm{O}_{7}-\mathrm{H}_{2} \mathrm{SO}_{4}$ oxidation-reduction titration method, respectively. Soil $\mathrm{pH}$ was measured using an MP521 Lab pH meter (Soil to water ratios: 1:2.5). Soil salinity was measured using an MP521 Lab conductivity meter (Soil to water ratios: 1:5). Soil basal respiration in laboratory conditions was measured according to the method of Alef and Nannipieri (1995).

Soil microbial metabolic activity was measured by Biolog Ecoplates ${ }^{\mathrm{TM}}$ (Biolog, Hayward, CA, USA). The plates had 96 wells (i.e., one water blank and 31 sole C sources, each replicated three times). Soil suspensions were prepared by mixing $5 \mathrm{~g}$ soil into $45 \mathrm{~mL}$ of phosphate-buffered saline solution in sterile $100 \mathrm{~mL}$ centrifuge tubes, and then shaken $30 \mathrm{~min}$ on an orbital shaker. The suspension was diluted 1:1000 and then $150 \mu \mathrm{L}$ aliquots of each suspension were inoculated into the wells of the biolog microtiter plates. The biolog microtiter plates were incubated at $25{ }^{\circ} \mathrm{C}$ in constant temperature incubator. The color development in each plate well was recorded at $12 \mathrm{~h}$ intervals for $168 \mathrm{~h}$ at an optical density of $590 \mathrm{~nm}$. The microbial activity was expressed as AWCD value was determined according to the methods of Garland and Mills (1991). To calculate the utilization of $\mathrm{C}$ sources, the $96 \mathrm{~h}$ optical density values were normalized by dividing them by their AWCD.

\section{Data analyses}

All variance (ANOVA) analyses were conducted using SPSS19.0 statistical software. The difference between the groups used Tukey's test method $(\mathrm{P}<0.05)$. Principal components analysis (PCA) was conducted using Canoco 4.5 software. The heatmap and correlation analyses were generated using $\mathrm{R}$ package.

\section{Results}

\section{Soil properties}

Irrigation with saline water increased markedly soil salinity but reduced soil $\mathrm{pH}$, total N, and SOM (Figure 2). Nitrogen application significantly increased soil salinity, SOM, and total N, but reduced soil pH. Soil salinity was $474 \%$ greater in SWN0 than that in 
FWN0, and 346\% greater in SWN360 than that in FWN360. Soil pH, total N, and SOM were 3.7, 6.2, and 8.2\% less in SWN0 than that in FWN0. In comparison, soil pH, total $\mathrm{N}$, and SOM were 2.5, 14.2, and 5.1\% less in SWN360 than that in FWN360.
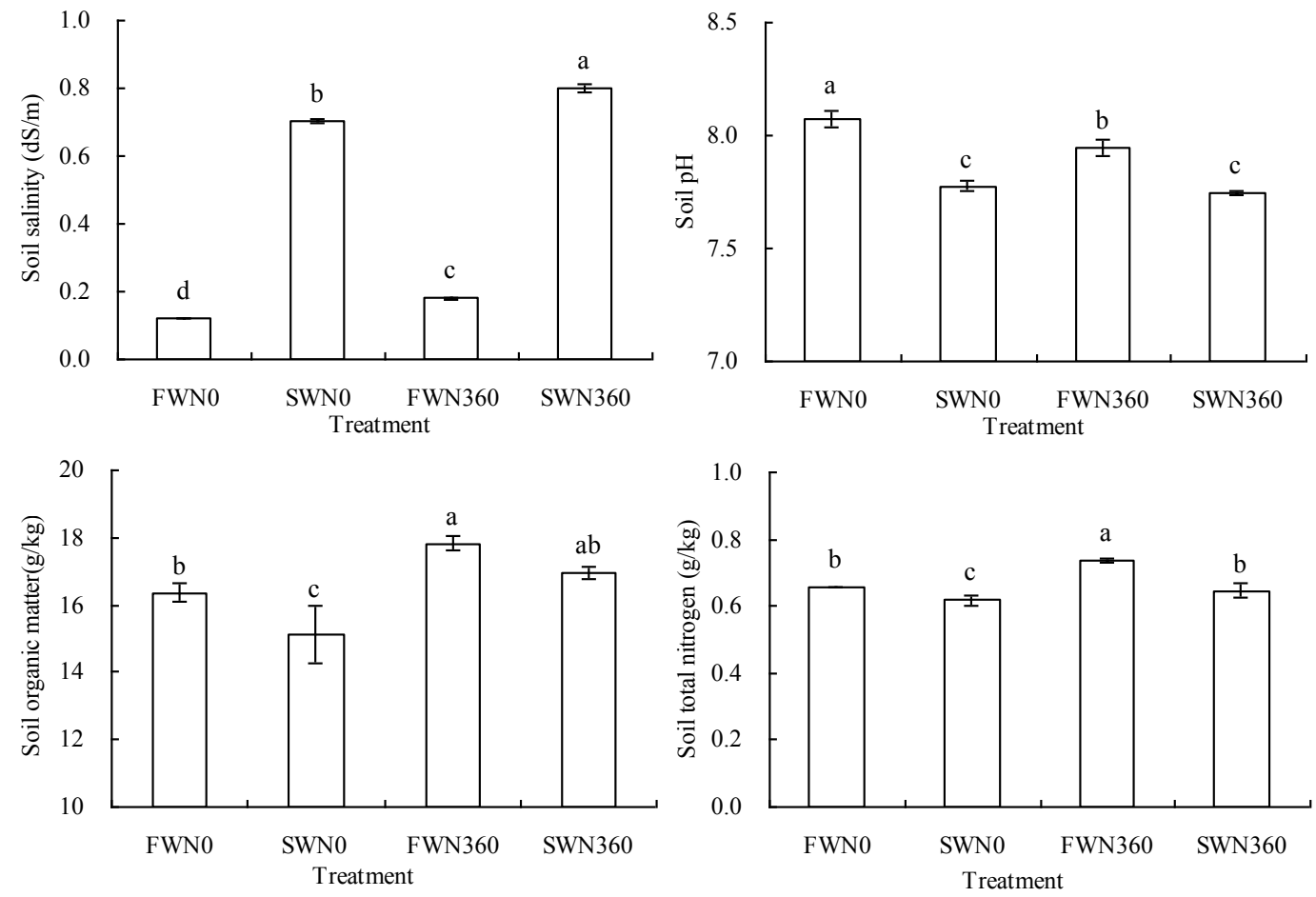

Figure 2. Soil salinity, $p H$, organic matter, and total $N$ as affected by irrigation water salinity and $N$ amount. Note: Values are the mean of three replicates. Error bars represent standard deviations. Different letters within the same panel indicate significant differences at $P<0.05$.

Abbreviations: $F W N 0$, fresh water with no $N$ fertilizer; $F W N 360$, fresh water with $360 \mathrm{~kg} \mathrm{~N} \mathrm{ha} a^{-1}$; SWNO, fresh water with no N fertilizer; SWN360, fresh water with $360 \mathrm{~kg} \mathrm{~N} \mathrm{ha}^{-1}$

\section{Soil basal respiration $(S B R)$}

Saline water irrigation significantly decreased SBR (Figure 3). Nitrogen application significantly increased SBR. SBR was $51.6 \%$ greater in FWN0 than that in SWN0, and $31.6 \%$ greater in FWN360 than that in SWN360. Averaged across two N amounts, irrigation with saline water reduced SBR by $28.4 \%$. Averaged across two water salinities, $\mathrm{N}$ application increased SBR by $35.1 \%$.

\section{Soil microbial metabolic activity}

AWCD is widely used to quantify soil microbial metabolic activity. There was little change in AWCD during the first $48 \mathrm{~h}$ of the incubation (Figure 4). After this lag phase, however, the AWCD values increased markedly. The increase rates varied depending on the treatment. For example, AWCD after $60 \mathrm{~h}$ increased more slowly in SWN0, and SWN360 than that in FWN0 and FWN360. There was no significant difference in AWCD between SWN0 and SWN360 after $96 \mathrm{~h}$. The accumulative AWCD values decreased in the order FWN0 > FWN360 > SWN0 > SWN360. 


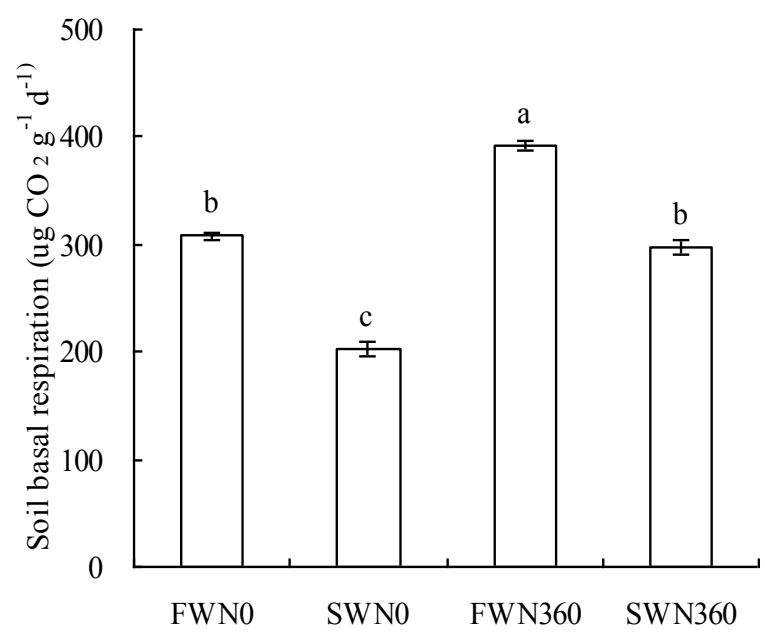

Figure 3. Soil basal respiration as affected by irrigation water salinity and $N$ amount. Note: Values are the mean of three replicates. Error bars represent standard deviations. Different letters within the same panel indicate significant differences at $P<0.05$. Abbreviations: FWNO, fresh water with no N fertilizer; FWN360, fresh water with $360 \mathrm{~kg} \mathrm{~N} \mathrm{ha}^{-1}$; SWNO, fresh water with no $\mathrm{N}$ fertilizer; $S W N 360$, fresh water with $360 \mathrm{~kg} \mathrm{~N} \mathrm{ha}^{-1}$

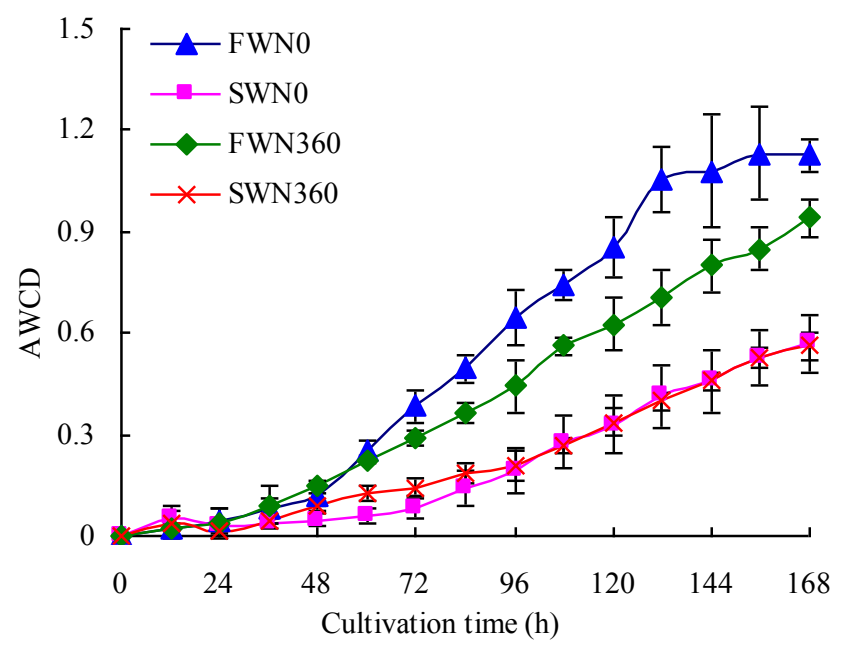

Figure 4. Average well color development during a 168-h incubation as affected by irrigation water salinity and $N$ amount. Note: Values are the mean of three replicates. Error bars represent standard deviations. Abbreviations: FWNO, fresh water with no N fertilizer; FWN360, fresh water with $360 \mathrm{~kg} \mathrm{~N} \mathrm{ha}^{-1}$; SWNO, fresh water with no N fertilizer; SWN360, fresh water with $360 \mathrm{~kg} \mathrm{~N} \mathrm{ha}^{-1}$

The ANOVA analyses results also showed that saline water irrigation and $\mathrm{N}$ fertilizer amount significantly altered soil microbial metabolic activity (Table 2). $\mathrm{N}$ fertilizer application significantly reduced AWCD in the FW treatments. However, $\mathrm{N}$ fertilizer application had no significant impact on AWCD in the SW treatments. The main effect means were $175 \%$ higher in FW than that in SW, and 23\% higher in N0 than that in N360. 
Table 2. Average well color development (AWCD) and six biochemical categories of substrates as affect under different treatments

\begin{tabular}{c|c|c|c|c|c|c|c}
\hline Treatment & AWCD & Carbohydrates & Amino acids & Carboxylic acids & Amines & Phenols & Polymers \\
\hline FWN0 & $0.648 \mathrm{a}$ & $1.006 \mathrm{a}$ & $0.587 \mathrm{a}$ & $0.522 \mathrm{a}$ & $0.471 \mathrm{a}$ & $0.386 \mathrm{a}$ & $0.281 \mathrm{a}$ \\
SWN0 & $0.191 \mathrm{c}$ & $0.325 \mathrm{c}$ & $0.149 \mathrm{c}$ & $0.153 \mathrm{~b}$ & $0.052 \mathrm{~b}$ & $0.022 \mathrm{~b}$ & $0.139 \mathrm{a}$ \\
FWN360 & $0.443 \mathrm{~b}$ & $0.778 \mathrm{~b}$ & $0.332 \mathrm{~b}$ & $0.386 \mathrm{a}$ & $0.046 \mathrm{~b}$ & $0.036 \mathrm{~b}$ & $0.271 \mathrm{a}$ \\
SWN360 & $0.206 \mathrm{c}$ & $0.423 \mathrm{c}$ & $0.097 \mathrm{c}$ & $0.162 \mathrm{~b}$ & $0.039 \mathrm{~b}$ & $0.015 \mathrm{~b}$ & $0.080 \mathrm{a}$ \\
\hline
\end{tabular}

Note: Different letters within a column and within a factor indicate significant differences among individual treatments $(P<0.05)$. Abbreviations: FWN0, fresh water with no $\mathrm{N}$ fertilizer; FWN360, fresh water with $360 \mathrm{~kg} \mathrm{~N} \mathrm{ha}^{-1}$; SWN0, fresh water with no N fertilizer; SWN360, fresh water with 360 $\mathrm{kg} \mathrm{N} \mathrm{ha-1}$

\section{Different biochemical categories of substrates}

The average absorbance of each carbon source category at $96 \mathrm{~h}$ were shown in Figure 5. There were significant differences in substrate use patterns under water salinity and $\mathrm{N}$ amount treatments. For example, amines and phenols were the least utilized by soil microbial communities in FWN360, whereas phenols were least utilized in SWN0 and SWN360. These results indicated distinct differences in microbial community structures among the treatments. Nitrogen application increased the utilization of carboxylic acids and carbohydrates both in the FW and SW treatments. Saline water irrigation increased carbohydrate utilization both in N0 and in N360 treatment.

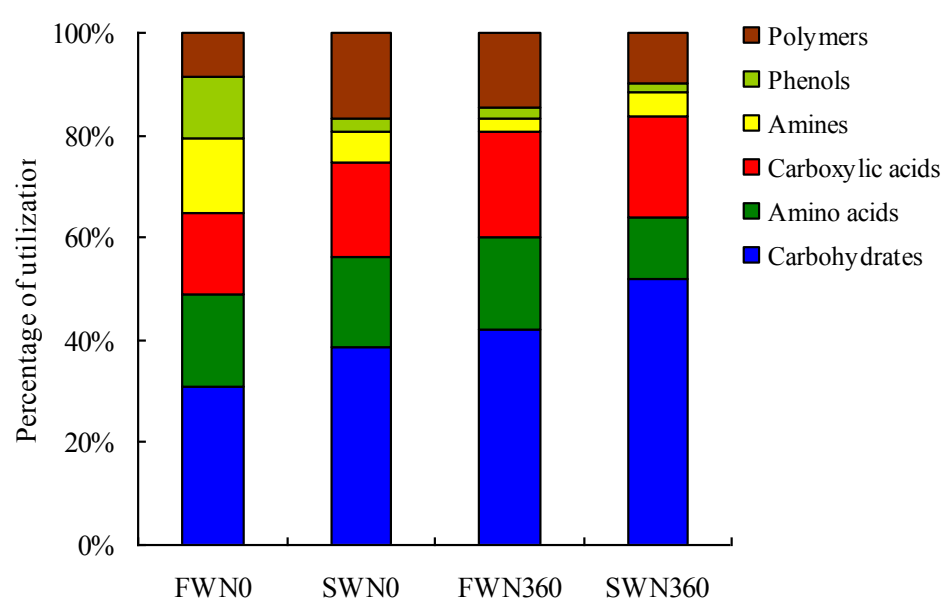

Figure 5. Utilization percentages of six categories of carbon substrates as affected by irrigation water salinity and $N$ amount. Abbreviations: $F W N O$, fresh water with no $N$ fertilizer; FWN360, fresh water with $360 \mathrm{~kg} \mathrm{~N} \mathrm{ha}^{-1}$; SWNO, fresh water with no N fertilizer; SWN360, fresh water with $360 \mathrm{~kg} \mathrm{~N} \mathrm{ha}^{-1}$

The ANOVA analyses results indicated that saline water irrigation and $\mathrm{N}$ fertilizer amount significantly affected the utilization of amino acids, amines, and phenols (Table 2). The three substrates utilization rates were greatest in FWN0. Irrigation water salinity also significantly affected the utilization of carbohydrates, carboxylic acids, and polymers. In addition, the highest substrates utilization rates of those compounds were 
in FWN0 and FWN360. Nitrogen fertilizer had no significant effect on carbohydrate, carboxylic acid, and polymer utilization.

Figure 6 shows a heatmap of $\mathrm{C}$ substrate utilization as influenced by water salinity and $\mathrm{N}$ amount. The sole $\mathrm{C}$ source uptake varied among the treatments. Saline irrigation water significantly decreased the utilization of D-cellobiose, D-xylose, $\beta$-methyl-dglucoside, i-erythritol, and D-mannitol $(\mathrm{P}<0.05)$ in both the N0 and N360 treatments. Nitrogen fertilizer significantly decreased i-erythritol utilization but had no significant influence on the utilization of D-cellobiose, $\beta$-methyl-D-glucoside, and D-xylose in FW or in SW. In addition, $\alpha$-D-lactose utilization was greatest in FWN0. Irrigation water salinity and $\mathrm{N}$ amount had no significant influence on the utilization of $\mathrm{N}$-acetyl-Dglucosamine, glucose-1-phosphate, D, L- $\alpha$-glycerol phosphate, and D-galactonic acid $\gamma$ lactone $(\mathrm{P}>0.05)$.

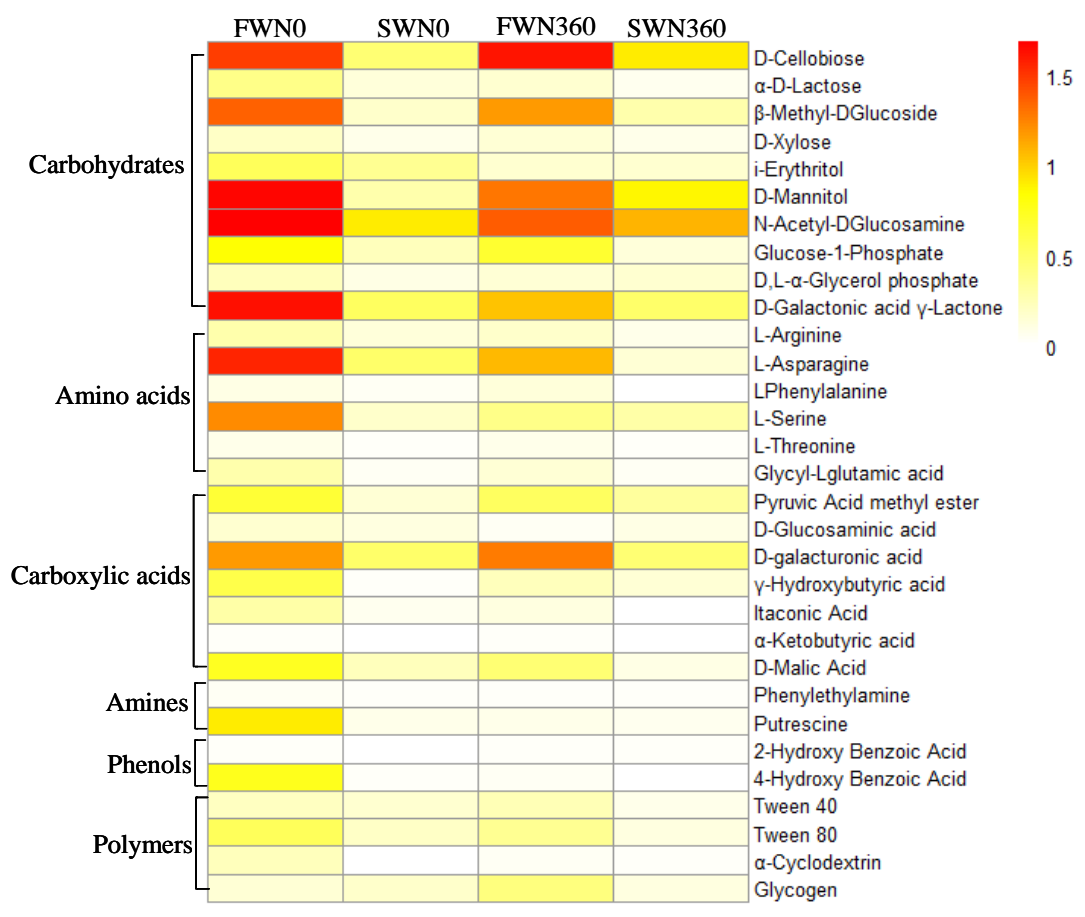

Figure 6. Heatmap showing the utilization of 31 carbon substrates as influenced by irrigation water salinity and $N$ amount. Abbreviations: $F W N O$, fresh water with no $N$ fertilizer; $F W N 360$, fresh water with $360 \mathrm{~kg} \mathrm{~N} \mathrm{ha}{ }^{-1}$; SWNO, fresh water with no N fertilizer; SWN360, fresh water with $360 \mathrm{~kg} \mathrm{~N} \mathrm{ha}^{-1}$

Regarding amino acids, L-serine utilization was greatest in FWNO. L-asparagine utilization was significantly higher (i) in FW than that in SW, and (ii) in N0 than that in N360 ( $<$ < 0.05). Compared with FW treatment, SW treatment significantly reduced L-phenylalanine utilization, whereas there was no significant difference in L-phenylalanine utilization between N0 and N360. Neither irrigation water salinity nor $\mathrm{N}$ amount had significant impact on the utilization of L-arginine, L-threonine, and glycyl-L-glutamic acid. The SW treatment significantly reduced carboxylic acid utilization, especially the utilization of $\gamma$-hydroxybutyric acid $(\mathrm{P}<0.05)$. The SW treatment significantly reduced the utilization of amines and phenols, especially the utilization of putrescine and 4-hydroxy benzoic acid $(\mathrm{P}<0.05)$. 
A PCA analysis was used to confirm the impact of water salinity and $\mathrm{N}$ amount on sole carbon source utilization. The first axes and the second axes together explained $88.8 \%$ of the total variation (Figure 7). The PCA clearly separated the soil samples according to the water salinity or $\mathrm{N}$ amount. This indicated significantly different microbial communities and patterns of potential carbon utilization among the treatments. There were three clusters: (1) FWN0; (2) FWN360; (3) SWN0 and SWN360.

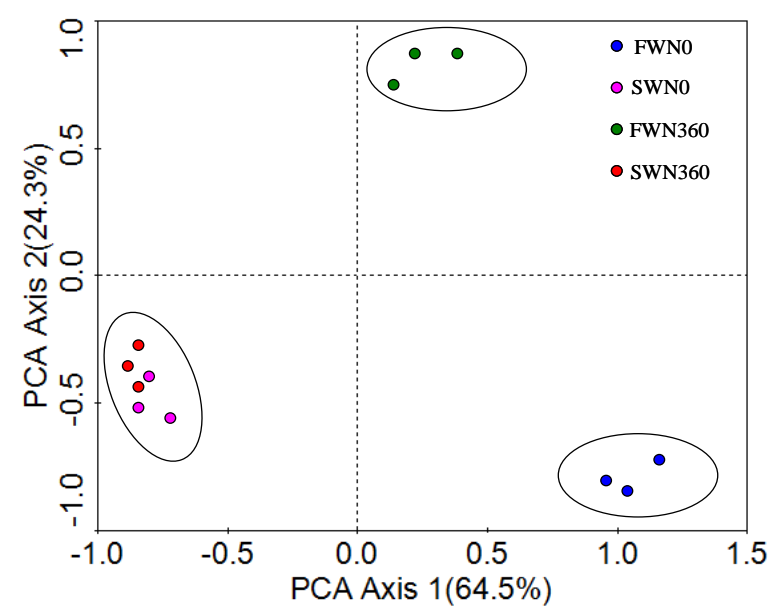

Figure 7. Principal coordinate analysis (PCA) of carbon source utilization profiles as affected by irrigation water salinity and $N$ fertilization. The resulting plots of 12 samples. Abbreviations: FWNO, fresh water with no N fertilizer; FWN360, fresh water with $360 \mathrm{~kg} \mathrm{~N} \mathrm{ha}^{-1}$; SWNO, fresh water with no N fertilizer; SWN360, fresh water with $360 \mathrm{~kg} \mathrm{~N} \mathrm{ha}^{-1}$

\section{Correlation analyses}

Soil salinity (EC1:5) was negatively correlated with soil basal respiration, AWCD and the six categories of carbon source utilization (Figure 8). Soil $\mathrm{pH}$ was positively correlated with AWCD and the six categories of carbon source utilization. SOM and total $\mathrm{N}$ was positively correlated with soil basal respiration However, neither SOM nor total $\mathrm{N}$ were significantly correlated with AWCD or carbon source utilization.

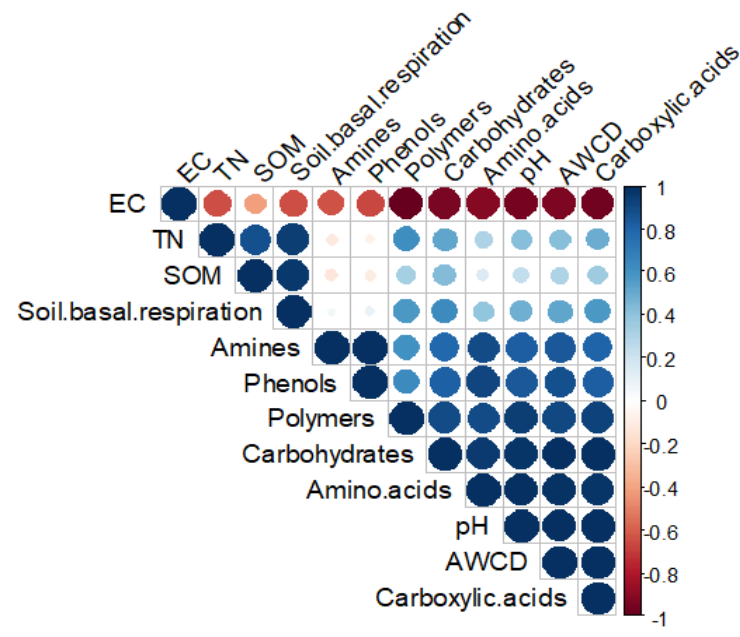

Figure 8. Correlations between selected soil chemical properties and carbon source utilization 


\section{Discussion}

The use of saline irrigation water is likely to increase in the future, especially in developing countries where there is extreme shortage of freshwater. However, long term saline water irrigation may alter soil properties, for instance, soil physicochemical properties and microbial metabolic activity. In our study, irrigation with saline water increased soil salinity. It was previously also found that saline water irrigation increased soil salinity (Huang et al., 2011; Ahmed et al., 2012). Our results agree with Villa-Castorena et al. (2003) who found that $\mathrm{N}$ fertilizer application increased soil salinity. Soil $\mathrm{pH}$ declined when the soil was fertilized with $\mathrm{N}$, this agrees with the report of Enwall et al. (2005). In this study, soil $\mathrm{pH}$ decreased with irrigation water salinity increased, one explanation is that the accumulation of strong acidic ions (e.g. $\mathrm{NO}_{3}{ }^{-}$, $\mathrm{SO}_{4}{ }^{2-}$ and $\mathrm{Cl}^{-}$) in salinized soil (Fan et al., 2009). Salinity was identified as one of the most potent environmental factors affecting soil microorganisms. Some researchers have reported on interaction between soil salinity and microbial activity. For instance, Rietz and Haynes (2003) and Yuan et al. (2007) found that salt conditions obviously inhibit soil microbial communities and their biochemical activities. Saline water irrigation will increase salt accumulation in the root zone and have adverse effects not only on soil physicochemical properties but also on microbial metabolic activities. Our results agree with observations that saline water irrigation for ten years decreased soil basal respiration, mainly due to osmotic stress in salinized soil (Mavi and Marschner, 2013). The carbon source utilization efficiency was an important factor influencing soil microbial communities activities in salt affected soils (Chen et al., 2017a). In this study, AWCD was less in saline water irrigation than in fresh water irrigation. This result indicated that irrigation with saline water could restrain soil microbial metabolic activities and affect substrate utilization patterns. In addition, Rietz and Haynes (2003) also reported that a negative relationship between soil microbial activity and soil salt. One explanation is that increased soil salinity lead to more stressed, a smaller soil microbial community which was lower carbon source utilization efficiency.

Fertilization application may indirectly or directly influence soil chemical, physical, and biological properties (Marschner et al., 2003; Hai et al., 2010). Nitrogen fertilization may influence soil microbial metabolic activities through a variety of mechanisms, for example by altering microbial biomass, diversity, and labile carbon inputs by soil microbial (Phillips et al., 2015; Miura et al., 2016). However, the effects of $\mathrm{N}$ fertilization vary depending on soil environment, original $\mathrm{N}$ content, plant species, and other factors (Rath and Rousk, 2015). In this study, $\mathrm{N}$ fertilization for ten years reduced soil microbial metabolic activities in fresh water irrigation, but had no significant effect in saline water irrigation. In addition, $\mathrm{N}$ fertilization application increased soil basal respiration in this study. Sarathchandra et al. (2001) also reported that 200 and $400 \mathrm{~kg} \mathrm{~N} / \mathrm{ha}$ markedly reduced soil microbial metabolic activities compared with an unfertilized treatment. He et al. (2007) reported that the primary reason why soil microbial metabolic activities declined in $\mathrm{N}$ fertilized soil was that the $\mathrm{N}$ fertilizer reduced soil $\mathrm{pH}$.

The Biolog Ecoplates can be used as a method to make preliminary comparisons of the soil microbial metabolic activities on all the substrates; however, this method does not provide specific metabolic property on each categories of carbon source utilization (Zhang et al., 2014). Some soil microbial may prefer to utilize amino acids, and others may tend to utilize carbohydrates. Chen et al. (2017b) found that different utilization rate of carbohydrates, amino acids, carboxylic acids, and polymers by soil microbial 
communities under different saline irrigation and fertilization regimes. Our study showed that the utilization of six substrate categories was markedly different in saline water irrigation than that in fresh water irrigation. In addition, irrigation water salinity and $\mathrm{N}$ amount markedly influenced the utilization rates of amines, amino acids, and phenols, which demonstrated that these three categories are sensitive indicators for distinguishing carbon source utilization under different irrigation water salinity and $\mathrm{N}$ amount treatments by soil microbial communities. Overall, the results showed that microbial in saline water irrigated soils may decrease their use of one carbon source, but increase their use of another. The result is that the total metabolic activity is sustained. Meanwhile, the significant correlations between above carbon categories and soil chemical properties were highly consistent with the AWCD. For example, soil salinity $\left(\mathrm{EC}_{1: 5}\right)$ was negatively correlated with $\mathrm{AWCD}$ and the six categories of carbon source utilization. This agrees with the report of Min et al. (2016). Based on experimental results, we concluded that D-cellobiose, $\beta$-methyl-d-glucoside, D-xylose, i-erythritol, D-mannitol, $\alpha$-D-lactose, L-serine, L-asparagine, L-phenylalanine, $\gamma$-hydroxybutyric acid, putrescine and 4-hydroxy benzoic acid were the sole carbon substrate categories for distinguishing the carbon source utilization rate of each category by the soil microorganisms. However, the Biolog Ecoplates technique only analyzes the cultivable soil microbial community activities. For more accurate assessment, future work needs to be done based on functional groups and molecular methods.

\section{Conclusions}

In this study, we quantified the effects of ten years of saline water irrigation on soil properties and microbial metabolic activities under drip-irrigated cotton field in arid area. Ten years saline irrigation water and $\mathrm{N}$ application may alter soil properties and significantly influence microbial metabolic activities. The soil basal respiration and microbial metabolic activities were higher in fresh water irrigation than in saline water irrigation. Nitrogen application significantly reduced soil microbial metabolic activities in the fresh water treatments but had no significant effect in the saline water treatments. The amino acids, amines, and phenols utilization rate decisively impact the carbon source utilization under different irrigation water salinity and $\mathrm{N}$ fertilizer rate. This study results increase understanding about soil biological processes under saline conditions. In the future, we should focus on the improvement of saline soil, to explore the improvement effect of straw returning and biochar application on saline soil, and provide a theoretical basis for the utilization of saline water and improvement of saline soil in arid areas.

Acknowledgments. This work was jointly funded by The National Natural Science Foundation of China [41661055], the Youth Innovation Talent Cultivation Program of Shihezi University [CXRC201706].

\section{REFERENCES}

[1] Ahmed, C. B., Magdich, S., Rouina, B. B., Boukhris, M., Abdullah, F. B. (2012): Saline water irrigation effects on soil salinity distribution and some physiological responses of field grown Chemlali olive. - Journal of environmental management 113: 538-544.

[2] Alef, K., Nannipieri, P. (1995): Methods in applied soil microbiology and biochemistry. Academic, London, pp. 214-219. 
[3] Amini, S., Ghadiri, H., Chen, C., Marschner, P. (2016): Salt-affected soils, reclamation, carbon dynamics, and biochar: a review. - Journal of soils and sediments 16(3): 939-953.

[4] Campbell, B. J., Kirchman, D. L. (2013): Bacterial diversity, community structure and potential growth rates along an estuarine salinity gradient. - The ISME journal 7(1): 210220.

[5] Chen, W., Hou, Z., Wu, L., Liang, Y., Wei, C. (2010): Evaluating salinity distribution in soil irrigated with saline water in arid regions of northwest China. - Agricultural water management 97(12): 2001-2008.

[6] Chen, L., Li, C., Feng, Q., Wei, Y., Zheng, H., Zhao, Y., Feng, Y., Li, H. (2017a): Shifts in soil microbial metabolic activities and community structures along a salinity gradient of irrigation water in a typical arid region of China. - Science of the Total Environment 598: 64-70.

[7] Chen, L. J., Feng, Q., Wei, Y. P., Li, C. S., Zhao, Y., Li, H. Y., Zhang, B. G. (2017b): Effects of saline water irrigation and fertilization regimes on soil microbial metabolic activity. - Journal of Soils and Sediments 17(2): 376-383.

[8] Chowdhury, N., Yan, N., Islam, M. N., Marschner, P. (2011a): The extent of drying influences the flush of respiration after rewetting in non-saline and saline soils. - Soil Biology and Biochemistry 43(11): 2265-2272.

[9] Chowdhury, N., Marschner, P., Burns, R. G. (2011b): Soil microbial activity and community composition: impact of changes in matric and osmotic potential. - Soil Biology and Biochemistry 43: 1229-1236.

[10] Chowdhury, N., Marschner, P., Burns, R. G. (2011c): Response of microbial activity and community structure to decreasing soil osmotic and matric potential. - Plant and Soil 344: 241-254.

[11] Conde, E., Cardenas, M., Ponce-Mendoza, A., Luna-Guido, M. L., Cruz-Mondragón, C., Dendooven, L. (2005): The impacts of inorganic nitrogen application on mineralization of 14 C-labelled maize and glucose, and on priming effect in saline alkaline soil. - Soil Biology and Biochemistry 37(4): 681-691.

[12] Craine, J. M., Morrow, C., Fierer, N. (2007): Microbial nitrogen limitation increases decomposition. - Ecology 88(8): 2105-2113.

[13] Critter, S. A., Freitas, S. S., Airoldi, C. (2004): Microcalorimetric measurements of the metabolic activity by bacteria and fungi in some Brazilian soils amended with different organic matter. - Thermochimica Acta 417(2): 275-281.

[14] Enwall, K., Philippot, L., Hallin, S. (2005): Activity and composition of the denitrifying bacterial community respond differently to long-term fertilization. - Applied and environmental microbiology 71(12): 8335-8343.

[15] Fan, Q. F., Zhang, Y. L., Chen, Z., Wang, L. N., Lou, Y. L. (2009): Effects of soil salinity accumulating and ion constitution on $\mathrm{pH}$ in the soil of protected field. - Agricultural Research in the Arid Areas 1: 006.

[16] Garland, J. L., Mills, A. L. (1991): Classification and characterization of heterotrophic microbial communities on the basis of patterns of community-level sole-carbon-source utilization. - Applied and environmental microbiology 57(8): 2351-2359.

[17] Gennari, M., Abbate, C., Porta, V. L., Baglieri, A., Cignetti, A. (2007): Microbial response to $\mathrm{Na}_{2} \mathrm{SO}_{4}$ additions in a volcanic soil. - Arid Land Research and Management 21(3): 211-227.

[18] Gros, R., Poly, F., Monrozier, L. J., Faivre, P. (2003): Plant and soil microbial community responses to solid waste leachates diffusion on grassland. - Plant and soil 255(2): 445-455.

[19] Hai, L., Li, X. G., Li, F. M., Suo, D. R., Guggenberger, G. (2010): Long-term fertilization and manuring effects on physically-separated soil organic matter pools under a wheatwheat-maize cropping system in an arid region of China. - Soil Biology and Biochemistry 42(2): 253-259. 
[20] He, J. Z., Shen, J. P., Zhang, L. M., Zhu, Y. G., Zheng, Y. M., Xu, M. G., Di, H. (2007): Quantitative analyses of the abundance and composition of ammonia-oxidizing bacteria and ammonia-oxidizing archaea of a Chinese upland red soil under long-term fertilization practices. - Environmental Microbiology 9(9): 2364-2374.

[21] Hobbie, S. E., Vitousek, P. M. (2000): Nutrient limitation of decomposition in Hawaiian forests. - Ecology 81(7): 1867-1877.

[22] Huang, C. H., Xue, X., Wang, T., De, M. R., Mele, G., You, Q. G., Peng, F., Tedeschi, A. (2011): Effects of saline water irrigation on soil properties in northwest China. Environmental Earth Sciences 63(4): 701-708.

[23] Jin, Z. Z., Lei, J. Q., Li, S. Y., Xu, X. W. (2014): Characteristics of sandy soil microbial metabolisms in the forests drip irrigation with saline water. - Journal of Desert Research 34: 363-370. (In Chinese with English abstract).

[24] Kakumanu, M. L., Williams, M. A. (2014): Osmolyte dynamics and microbial communities vary in response to osmotic more than matric water deficit gradients in two soils. - Soil Biology and Biochemistry 79: 14-24.

[25] Karlberg, L., Rockström, J., Annandale, J. G., Steyn, J. M. (2007): Low-cost drip irrigation-A suitable technology for southern Africa?: An example with tomatoes using saline irrigation water. - Agricultural Water Management 89(1): 59-70.

[26] Kaye, J. P., McCulley, R. L., Burke, I. C. (2005): Carbon fluxes, nitrogen cycling, and soil microbial communities in adjacent urban, native and agricultural ecosystems. Global Change Biology 11(4): 575-587.

[27] Llamas, D. P., de Cara Gonzalez, M., Gonzalez, C. I., Lopez, G. R., Marquina, J. C. T. (2008): Effects of water potential on spore germination and viability of Fusarium species. - Journal of industrial microbiology \& biotechnology 35(11): 1411-1418.

[28] Malik, A., Gleixner, G. (2013): Importance of microbial soil organic matter processing in dissolved organic carbon production. - FEMS microbiology ecology 86(1): 139-148.

[29] Mandeel, Q. A. (2006): Biodiversity of the genus Fusarium in saline soil habitats. Journal of Basic Microbiology 46(6): 480-494.

[30] Manzoni, S., Schimel, J. P., Porporato, A. (2012): Responses of soil microbial communities to water stress: results from a meta-analysis. - Ecology 93(4): 930-938.

[31] Marschner, P., Kandeler, E., Marschner, B. (2003): Structure and function of the soil microbial community in a long-term fertilizer experiment. - Soil Biology and Biochemistry 35(3): 453-461.

[32] Mavi, M. S., Sanderman, J., Chittleborough, D. J., Cox, J. W., Marschner, P. (2012): Sorption of dissolved organic matter in salt-affected soils: Effect of salinity, sodicity and texture. - Science of the Total Environment 435: 337-344.

[33] Mavi, M. S., Marschner, P. (2013): Salinity affects the response of soil microbial activity and biomass to addition of carbon and nitrogen. - Soil Research 51(1): 68-75.

[34] Min, W., Guo, H., Zhang, W., Zhou, G., Ma, L., Ye, J., Liang, Y. C., Hou, Z. (2016): Response of soil microbial community and diversity to increasing water salinity and nitrogen fertilization rate in an arid soil. - Acta Agriculturae Scandinavica, Section BSoil \& Plant Science 66(2): 117-126.

[35] Miura, T., Owada, K., Nishina, K., Utomo, M., Niswati, A., Kaneko, N., Fujie, K. (2016): The effects of nitrogen fertilizer on soil microbial communities under conventional and conservation agricultural managements in a tropical clay-rich ultisol. - Soil Science 181(2): 68-74.

[36] Muhammad, S., Müller, T., Joergensen, R. G. (2008): Relationships between soil biological and other soil properties in saline and alkaline arable soils from the Pakistani Punjab. - Journal of Arid Environments 72: 448-457.

[37] Oren, A. (2008): Microbial life at high salt concentrations: phylogenetic and metabolic diversity. - Saline systems 4(1): 2. 
[38] Pangle, R. E., Seiler, J. (2002): Influence of seedling roots, environmental factors and soil characteristics on soil $\mathrm{CO}_{2}$ efflux rates in a 2-year-old loblolly pine (Pinus taeda L.) plantation in the Virginia Piedmont. - Environmental Pollution 116: S85-S96.

[39] Pereira, L. S., Oweis, T., Zairi, A. (2002): Irrigation management under water scarcity. Agricultural water management 57(3): 175-206.

[40] Phillips, L. A., Schefe, C. R., Fridman, M., O'Halloran, N., Armstrong, R. D., Mele, P. M. (2015): Organic nitrogen cycling microbial communities are abundant in a dry Australian agricultural soil. - Soil Biology and Biochemistry 86: 201-211.

[41] Ramirez, K. S., Craine, J. M., Fierer, N. (2010): Nitrogen fertilization inhibits soil microbial respiration regardless of the form of nitrogen applied. - Soil Biology and Biochemistry 42(12): 2336-2338.

[42] Rietz, D. N., Haynes, R. J. (2003): Effects of irrigation-induced salinity and sodicity on soil microbial activity. - Soil Biology and Biochemistry 35(6): 845-854.

[43] Sardinha, M., Müller, T., Schmeisky, H., Joergensen, R. G. (2003): Microbial performance in soils along a salinity gradient under acidic conditions. - Applied Soil Ecology 23(3): 237-244.

[44] Setia, R., Marschner, P., Baldock, J., Chittleborough, D., Verma, V. (2011): Relationships between carbon dioxide emission and soil properties in salt-affected landscapes. - Soil Biology and Biochemistry 43(3): 667-674.

[45] Shen, W., Lin, X., Gao, N., Zhang, H., Yin, R., Shi, W., Duan, Z. (2008): Land use intensification affects soil microbial populations, functional diversity and related suppressiveness of cucumber Fusarium wilt in China's Yangtze River Delta. - Plant and soil 306(1-2): 117-127.

[46] Villa-Castorena, M., Ulery, A. L., Catalán-Valencia, E. A., Remmenga, M. D. (2003): Salinity and nitrogen rate effects on the growth and yield of chile pepper plants. - Soil Science Society of America Journal 67(6): 1781-1789.

[47] Wong, V. N., Greene, R. S. B., Dalal, R. C., Murphy, B. W. (2010): Soil carbon dynamics in saline and sodic soils: a review. - Soil Use and Management 26(1): 2-11.

[48] Yan, N., Marschner, P. (2012): Response of microbial activity and biomass to increasing salinity depends on the final salinity, not the original salinity. - Soil Biology and Biochemistry 53: 50-55.

[49] Zhang, T. Y., Wu, Y. H., Zhuang, L. L., Wang, X. X., Hu, H. Y. (2014): Screening heterotrophic microalgal strains by using the Biolog method for biofuel production from organic wastewater. - Algal Research 6: 175-179. 